\title{
Lexical-Semantic Representations at the Time of the Coronavirus Pandemic
}

\author{
Daniele Franceschi ${ }^{1}$ \\ ${ }^{1}$ Department of Foreign Languages, Literatures and Cultures, 'Roma Tre' University, Rome, Italy \\ Correspondence: Daniele Franceschi, Department of Foreign Languages, Literatures and Cultures, 'Roma Tre' \\ University, Via Ostiense 234-236, 00146 Rome, Italy. E-mail: daniele.franceschi@uniroma3.it
}

Received: August 31, 2021

Accepted: October 18, $2021 \quad$ Online Published: November 4, 2021

doi:10.5539/ijel.v11n6p120

URL: https://doi.org/10.5539/ijel.v11n6p120

\begin{abstract}
This paper examines some cases of lexical adaptation and innovation in present-day English resulting from changed communicative needs brought about by the current coronavirus pandemic. The data analysed consists of 15 lexical items retrieved in the NOW Corpus, a web-based collection of newspapers and magazines freely accessible online. The study shows that certain already existing words and expressions tend to be used more frequently in coronavirus-related discourse than in other contexts prior to the current crisis; others appear to be undergoing a re-adaptation of their semantic range, while new ones seem to have emerged and to be making their way into dictionaries. At the same time, there are certain free-word combinations built "on the fly" whose stability is still uncertain.
\end{abstract}

Keywords: lexical innovation, semantic adaptation, coronavirus discourse

\section{Introduction}

The coronavirus pandemic has, all of a sudden, imposed new patterns of behaviour and new ways of thinking on everyone everywhere, with many repercussions at different levels of our lives. The structure of the world and our experience of it ultimately shape our thoughts and how we express them. In the last few months, we have been witnessing an increasing use of words and expressions to describe what was up until recently an unimaginable and unknown scenario. While there is no record of some of these lexical items before the coronavirus outbreak, in other cases their use was already documented, but their occurrence and distribution has seen a significant increase in 2020 and in the first half of 2021, to the extent that even some of the most authoritative dictionaries of English, e.g., the Oxford English Dictionary (OED), have started to include them. It has been amply demonstrated that, through repeated use, words and sequences of words eventually become lexicalized and part of the vocabulary of a language (Brinton \& Closs Traugott, 2005). It is hard to predict, however, the level of stability of new lexical items, but the extent of the impact of the current sanitary crisis on our societies and the need to talk about it seem to suggest that some of the observed linguistic innovations will most probably linger and others will emerge.

The present paper analyses 15 lexical items retrieved in reports on the coronavirus pandemic available in the online versions of newspapers and magazines from various countries where English is spoken both as a first and second language. The study is corpus-based and provides a quantitative and qualitative analysis of these elements as they appear in the NOW (News On the Web) corpus (Note 1). One of them is a phraseological unit (helicopter money), four lie astride the boundary between phrasemes and simple collocations (recovery bonds, recovery funds, corona bonds and corona funds), three are hybrid constructions with features of collocations and compounds (social distancing, smart working and wet market), two are on the way to becoming collocations (to close/reopen [a country]), two are proper compounds (lockdown and spillover) and, finally, three are free word-combinations (Chinese virus, China virus and anxiety pandemic). The aim here is also that of showing the cognitive processes underlying word formation, in an attempt to explain how and why new meanings come into existence.

The dividing line between one type of lexical element and the other is sometimes not so well defined. Hence, the confusion and variety of terms in the linguistic literature often describing the same or similar phenomena. What is the difference, for instance, between a 'phraseme' and a 'phraseological unit'? When does a 'free word-combination' become a 'collocation'? Is 'lexeme' a synonym for 'lexical unit'? Section 2 tries to answer 
these questions and to clear up the terminological confusion about related concepts. Section 3 explains the methodology followed for the selection and analysis of the data; section 4 is the core of the paper-the 15 lexical elements mentioned above are analysed with respect to their frequencies of occurrence, morpho-syntactic and semantic properties as well as in terms of the extra-linguistic factors motivating and guiding their formation. Finally, section 5 summarizes the research conducted and draws up some conclusions.

\section{Setting the Scene: Contrasting Terms and Definitions}

The lowest-level unit of lexical meaning is the 'lexeme'. It basically corresponds to a dictionary entry and it is to be distinguished from its specific instantiations or word forms (Note 2). For example, bad is an adjective lexeme, which can take three distinct forms, i.e., bad, worse and worst (Note 3); water as a noun lexeme has four forms, namely the neutral/plain singular water, the plural waters (e.g., when we implicitly and informally refer to two or more glasses or bottles of water), the genitive singular water's and possibly the genitive plural waters'; water also gets a separate dictionary entry as a (in)transitive verb and as such it appears in four different shapes, i.e., water, waters, watered, watering. We can thus argue that 'lexemes' are complete signs or abstract units of the language system projecting a certain number of manifestations.

The definition of 'lexical unit' is more troublesome, instead. It is generally taken to refer to the union of a lexical form and a single sense; for some linguists it typically consists of more than one word (Booij, 2014), while for others this is not a necessary condition (Lipka, 2002). Following the latter view, both the English phrase yellow fever and the word lunch may be treated as lexical units. In addition, lunch as a noun and lunch as a verb, in spite of their being homographs and homophones, also need to be considered as two distinct lexemes, because each of them has different sense relations (Note 4).

When approaching multiword combinations, there emerges the problem of the limits between 'compounds' and 'phraseological units' or 'phrasemes' (Note 5). The difference is not only morphological in nature. Although it is true that compounds may be written either as single words (babysitter), as two hyphenated words (baby-sitter) or as a series of consecutive words without punctuation or any other link between them (baby sitter, red carpet, chicken leg dinner, chicken and egg situation) (Note 6), the crucial difference is that compounds designate single concepts, while phraseological units maintain the meaning of their constituent parts (Meyer \& Mackintosh, 1994). Put differently, "we have a compound if the meaning of the whole cannot be logically deduced from the meaning of the elements separately" (Jespersen, 1942, p. 137). So, for instance, ice cream has its own meaning, which is not simply obtained by the sum of the meaning of ice and cream, and it is lexicalized, thus appearing in dictionaries. By contrast, *ice tea is not a unit of meaning and cannot be considered as a compound. We need to resort to a phrase, i.e., iced tea, to describe the concept of 'tea that has been iced'. We can argue then that phraseological units are not formed in the lexicon, but rather in the syntax (Bauer, 1988; Lieber \& Stekauer, 2009). That is why they cannot be easily categorized as a single part of speech and cannot be interrupted.

Unlike phraseological units, free word combinations simply consist of co-occurring words linked by means of syntactic relations and analytical functions. Their meaning is strictly compositional, because it is determined by the meaning of the constituent words, e.g., kick the ball. Both phraseological units and free word combinations are syntagmas, i.e., units of syntax. When there is a usage-determined or preferred syntagmatic relation between two words in a syntactic context we speak of 'collocations'. Compare, for instance, kick the ball with hard frost. The former allows for the alternation of kick with a synonym, so hit the ball would also be possible, for example. The substitution of hard with a synonymous word in hard frost would instead produce a wrong expression, e.g., *strong frost. This is because in hard frost the collocate (the adjective hard) is constrained by the meaning of the base (the noun frost) and vice versa. Collocations are not just lexical, but also grammatical when they involve the use of function words, typically prepositions. Therefore, hard frost is a lexical collocation, while cope with, interested in, a contribution to, and so on, are grammatical collocations (Note 7).

\section{Methodology}

Early in the pandemic, it soon became clear that the coronavirus would not only change our life habits, but also the languages that we speak. The Oxford English Dictionary started monitoring this unprecedented change in English from the very beginning and has since then dedicated a whole new section in the OED Blog to the language of Covid-19 (Note 8). This webpage was the main source of inspiration for the present analysis. The 15 lexical items examined here were chosen from the lists of the top 25 monthly keywords in the Oxford Corpus (Note 9) that are regularly published in the OED blog. Because access to the Oxford Corpus is restricted and not easily granted, it was decided to use the NOW Corpus, which has a comparable size and also shows us what is happening in the language virtually right up to the present time.

The choice of the words and expressions examined was made with the intent of exemplifying some cases of lexical 
change and innovation "brought about" by coronavirus discourse. The discussion could have included many more lexical items, but the final goal was not to account for all the new word uses and formations that have entered and are still entering the English language as a consequence of the pandemic, or to identify the most frequent ones in the corpus, but rather to investigate the general trends and dynamics of new form-meaning mappings from a broader perspective, in order to understand what motivates and makes them possible. The idea was to provide some insights into the context-dependence of lexical change and lexical emergence within the possibilities of the various word formation options in English.

\section{Old and New Lexical Representations: Strengthening vs. Emergence}

Two main lexical trends have been identified during the analysis of the 15 items under consideration. On the one hand, there has been a drastic increase in the use of the two compounds spillover and lockdown in 2020 and in the first half of 2021, even though they already existed before the coronavirus outbreak; this also applies to the two collocations social distancing and wet market. The other collocations and (phraseological) word combinations, on the other hand, are novel uses that are only starting to be represented in dictionaries.

4.1 Phraseological Units or Collocations? Helicopter Money vs Corona Bonds, Corona Funds, Recovery Bonds and Recovery Fund

It is often not easy to distinguish between phraseological units and collocations (Note 10), especially when the former become more stable and non-compositional in meaning due to repeated use. Helicopter money, for instance, is a fixed combination of words, despite its limited lexicographic coverage, while corona bonds and corona funds as well as recovery bonds and recovery funds, which are also scarcely represented, are more likely to be collocations allowing some lexical flexibility.

Helicopter money does not appear in the OED, but it is present in the Urban Dictionary (Note 11), even if the definition provided ('large amounts of money that bypasses the tax system and is moved into the pockets of wealthy households and companies through unfair tax credits and cuts at the expense of good working people') is more of a criticism than an actual description of the meaning of the expression. There is, however, a Wikipedia page, which more objectively defines the concept of helicopter money as a 'proposed unconventional monetary policy, sometimes suggested as an alternative to quantitative easing (QE) when the economy is in a liquidity trap (when interest rates [are] near zero and the economy remains in recession)' (Note 12). The expression seems to have been first used by the American economist Milton Friedman in a parable in 1969 to indicate the immediate beneficial effects of financial help on a large scale, as opposed to complex money injection mechanisms (Note 13). In the NOW Corpus, helicopter money is rather infrequent, the only exception being 2016 (Note 14). But there was an increase in its use in 2020 (see Table 1 below), as an obvious consequence of the discussion about the distribution of money to face the economic crisis resulting from the coronavirus pandemic. The total number of occurrences of helicopter money in 2020 amounts to 603, but there is a significant difference between the first and the second half of 2020, indicating perhaps that money distribution was more of an issue or a concern during and immediately after the first lockdown. The frequency of use of the expression appears to be rather low in the current year though, which again may indicate that web-based newspapers and magazines now give less prominence to the topic.

Table 1. Frequencies of occurrence of helicopter money in the NOW Corpus

\begin{tabular}{llllllll}
\hline & 2016 & 2017 & 2018 & 2019 & $2020-1$ & $2020-2$ & $2021-1$ \\
\hline FREQ & 869 & 32 & 31 & 118 & 441 & 162 & 102 \\
PER MIL & 1.12 & 0.03 & 0.04 & 0.12 & 0.16 & 0.06 & 0.08 \\
\hline
\end{tabular}

The interpretation of helicopter money requires a rather complex cognitive operation involving metaphor. The concept of a helicopter typically flying over a vast area is mapped onto a representation according to which the larger the area covered, the higher the number of people involved. This is a cross-domain mapping, because these two concepts are unrelated. The frames evoked by the words helicopter and money are exploited to produce an ad hoc phrase, creatively condensing two distinct images, thus making it possible to economically express the notion of distributing money to many people (as if it were dropped from a helicopter). Although it is a novel formation (Benczes, 2006), initially built "on the fly" to tie different concepts together and to conceptualize them as single units, its frequent occurrence in the corpus suggests that maybe it is beginning to be stored in the lexicon.

Recovery bonds, recovery funds, corona bonds and corona funds are also novel uses resulting from the fusion of 
distinct and originally unrelated concepts. However, while helicopter money is a fixed combination, these four expressions exhibit a higher level of lexical variability and three of them, namely recovery bonds, corona bonds and corona funds, appear neither in the OED nor in any other dictionary or database (Note 15). It is only recovery funds that seems to be attaining lexicographic status, as it can be retrieved in the financial section of The Free Dictionary (Note 16). Interestingly, the meaning of recovery funds, i.e., monetary compensation for people suffering a loss as a result of a breach of a real estate agent's or broker's responsibility, has been extended to refer more generically to money given to recover also from whatever other difficult financial situation, such as the one caused by the current coronavirus pandemic (e.g., COVID did not only hit the health of people; it hit the health of the economy [...]. The Commission plan is very clear about how to use the recovery funds, they can only be used in conjunction with [...].) (Note 17). One would expect several attestations of recovery funds from the area of finance prior to 2020, but in the NOW Corpus there are very few (Table 2). The use of the expression increased significantly in 2020 and it still is now. Only in the first half of 2021 there are 317 occurrences of recovery funds in the NOW Corpus. This trend may appear contradictory, since it does not reflect what we have observed in the case of helicopter money. After all, recovery funds also refer to the distribution of subsidies on a large scale. The latter expression, however, typically emerges in institutionalized political discourse and may thus be more widespread than helicopter money, which is instead more colloquial and less 'technical'.

Table 2. Frequencies of occurrence of recovery funds in the NOW Corpus

\begin{tabular}{lllllll}
\hline & 2016 & 2017 & 2018 & 2019 & 2020 & $2021-1$ \\
\hline FREQ & 13 & 24 & 39 & 58 & 301 & 317 \\
PER MIL & 0.02 & 0.03 & 0.05 & 0.05 & 0.12 & 0.24 \\
\hline
\end{tabular}

From a morphological perspective, corona bonds and corona funds are the result of a different morphological process compared to recovery bonds and recovery funds. First of all, the former are produced by clipping, so that coronavirus is first shortened as corona and then combined either with bonds or funds to implicitly refer to money given specifically to help people face the emergency situation caused by the virus. Recovery funds and recovery bonds are more general uses, which are however starting to express the same concept. Recovery bonds is far less frequent than recovery funds in the NOW Corpus. This could be related to the fact that the word bond is a specialized term.

\subsection{Collocations or Compounds? The Case of Social Distancing, Smart Working and Wet Market}

The boundary between collocations and compounds may be blurry (Note 18). This is because the tendency for certain lexemes to co-occur in the company of others often produces "crystallized" patterns that resist change: smart working, social distancing and wet market are indeed ambiguous with respect to their classification (Note 19). From a strictly semantic point of view, however, this issue is rather insignificant.

It is usually acknowledged that collocations, unlike compounds, do not form new lexemes (Fellbaum, 2007). This rigid distinction, however, does not seem to work in the case of social distancing, smart working and wet market, because their status is in flux. In other words, they retain some of the features of collocations, i.e., a simple "tendency to co-occur within a few words of each other" (Stubbs, 2001, p. 24) (Note 20), but it also looks as if they were on the way to becoming fixed combinations. This is particularly true for wet market, which has appeared in the OED since 1976 and may thus be treated as compound-like, because its meaning is conventionally established and does not allow lexical variation. The interpretation of wet market is based on a figurative understanding of 'market', whereby it is obviously not the market itself that is wet, but rather the fresh (i.e., uncooked) meat, fish and produce sold there. The meaning of the expression is thus not easily inferable from the meanings of the two elements, while compositionality is still strong in social distancing, but less so in smart working, which also requires a non-literal interpretation of 'smart'.

Smart working is absent in the OED and in other dictionaries (Note 21). In the NOW Corpus, the expression has occurred with considerable frequency since 2017, but, oddly enough, its use does not seem to have increased lately (Table 3), despite the fact that the current pandemic situation has imposed working from home via a number of devices, figuratively called 'smart'. 
Table 3. Frequencies of occurrence of smart working in the NOW Corpus

\begin{tabular}{llllll}
\hline & 2017 & 2018 & 2019 & 2020 & $2021-1$ \\
\hline FREQ & 13 & 160 & 123 & 173 & 58 \\
PER MIL & 0.01 & 0.19 & 0.13 & 0.07 & 0.04 \\
\hline
\end{tabular}

The changed working conditions that the coronavirus has brought across all sectors could possibly result in an increased use of the expression smart working in the future and, eventually, in its inclusion in dictionaries, since it economically encapsulates what has already become a popular concept (and activity) in our societies, as much as social distancing. The latter expression has been attested in the OED for a rather long time instead, but unlike smart working its frequency of occurrence in the NOW Corpus is extremely high already in 2020 and in the first half of 2021 (Table 4).

Table 4. Frequencies of occurrence of social distancing in the NOW Corpus

\begin{tabular}{llllll}
\hline & 2017 & 2018 & 2019 & 2020 & $2021-1$ \\
\hline FREQ & 12 & 5 & 9 & 274,427 & 44,052 \\
PER MIL & 0.02 & 0.01 & 0.01 & 105.23 & 33.46 \\
\hline
\end{tabular}

The reasons for these two different trends are difficult to explain. It could be argued, perhaps rather simplistically, that reducing close contact between people is so difficult and unnatural that it more easily becomes the object of conversation and discussion, although the data from the first half of 2021 suggest that the topic is perhaps becoming less talked about in the press. Similarly, in the case of wet market the NOW Corpus shows an increase in its use in 2020 and what appears to be a decrease in the current year, indicating a focus of attention shift in the press; over the years though, wet markets seem to have been more systematically mentioned (Table 5).

Table 5. Frequencies of occurrence of wet market in the NOW Corpus

\begin{tabular}{llllll}
\hline & 2017 & 2018 & 2019 & 2020 & $2021-1$ \\
\hline FREQ & 384 & 254 & 277 & 1,480 & 485 \\
PER MIL & 0.38 & 0.33 & 0.28 & 0.57 & 0.37 \\
\hline
\end{tabular}

\subsubsection{New Collocations? The Case of to Close/to Reopen the Country}

There are two very common expressions in coronavirus-related discourse in the media, i.e., to close/to reopen the country. They are not lexicalized collocations yet, but they have now started to appear with increasing frequency in newspapers and magazines. While to close the country has often been used in the past with reference to the idea of defending a country's borders (e.g., He accused those who want to close the country to refugees of hypocrisy) (Note 22), to reopen the country is insignificantly represented in the NOW Corpus before 2020 (Table 6), thus suggesting that this expression has acquired stability further to the coronavirus outbreak. Just like in the case of some of the other expressions discussed above, there appears to be a decrease in the use of to reopen the country in 2021. Perhaps, after much discussion about closures and re-openings, the media are now focusing more on other aspects of the pandemic.

Table 6. Frequencies of occurrence of to reopen the country in the NOW Corpus

\begin{tabular}{llllll}
\hline & 2017 & 2018 & 2019 & 2020 & $2021-1$ \\
\hline FREQ & 7 & 3 & 6 & 1,037 & 232 \\
PER MIL & 0.01 & 0.00 & 0.00 & 0.40 & 0.18 \\
\hline
\end{tabular}

Both to close the country and to reopen the country are figurative constructions only partially coding the meaning they express. Put differently, we cannot interpret 'closing a country' or 'reopening a country' literally, as if a country were a container, for instance. It is obvious that the word 'country' here stands for something more specific, i.e., the commercial activities, schools, workplaces, etc., of a country. Therefore, both to close the country and to reopen the country are metonymic patterns expressing concepts, which, for reasons of language economy and communicative efficiency, need to be communicated concisely. 


\subsection{Compounds: Spillover and Lockdown}

The compounds spillover and lockdown are present in the OED. The first attestation of spillover with the meaning of 'that which spills over; the process of spilling over; (an) incidental development; a consequence, a repercussion, a by-product' is quite recent and dates back to 1940 (Oregon: End of Trail (Federal Writers' Project) 34: The southern part of Oregon was occupied by..two 'spill-overs' from California - the Shastas and Karoks) (Note 23). The use of spillover in a medical sense, instead, appears in 1962 (Lancet 12 May 1009/1: 32 patients had pulmonary disease preoperatively, presumably owing to 'spill-over', and only in those with chronic pulmonary suppuration did this fail to clear up). In both examples, spillover is in inverted commas to indicate that it has been "imported" from another, more natural (i.e., prototypical) context, but the OED only lists the figurative uses of the compound.

The use of lockdown, with the meaning of 'confinement' at a certain place in response to a specific external threat, is even more recent than spillover and seems to have originated in American English. The original sense of 'confinement of prisoners to their cells for an extended period of time, usually as a measure following disturbance; the time at which such confinement begins; also in the context of a psychiatric hospital or other secure unit' is first documented in 1973, but it is only in 1984 that lockdown starts referring, more generically, to 'a state of isolation, containment, or restricted access, usually instituted for security purposes or as a public health measure; the imposition of this state' (United Press Internat. Newswire (Nexis) 14 Dec.: They instituted a 'security lockdown' at the PUREX plant Monday when a can containing..plutonium sludge was found to be missing)'.

In the NOW Corpus, spillover is present and evenly distributed. Its raw frequency has progressively increased since 2010, with peaks of 738 and 877 occurrences in the second half of 2017 and in the first half of 2019, respectively. The second half of 2019 has instead seen a decrease, but in 2020 and in the first half of 2021 the numbers have increased (Table 7). Although it would be necessary to analyse each use of spillover in order to identify its exact meaning in context, it seems obvious that its higher frequency is a consequence of the coronavirus outbreak and that its most likely meaning is now that of 'transfer of a virus from one living species to another'.

Table 7. Frequencies of occurrence of spillover in the NOW Corpus

\begin{tabular}{lllllllll}
\hline & $2017-1$ & $2017-2$ & $2018-1$ & $2018-2$ & $2019-1$ & $2019-2$ & 2020 & $2021-1$ \\
\hline FREQ & 684 & 738 & 599 & 722 & 877 & 630 & 2,363 & 1,288 \\
PER MIL & 0.80 & 0.83 & 0.80 & 0.83 & 0.88 & 0.64 & 0.91 & 0.98 \\
\hline
\end{tabular}

We are witnessing a similar trend in the case of lockdown, even if its overall frequency in the NOW Corpus is much higher than that of spillover. In addition, there has been an exponential increase in the use of lockdown in 2020 compared to 2019 and its frequency is still high in the first part of 2021 (Table 8), while that of spillover has only modestly increased in the same period.

Table 8. Frequencies of occurrence of lockdown in the NOW Corpus

\begin{tabular}{lllllllll}
\hline & $2015-1$ & $2015-2$ & $2016-1$ & $2016-2$ & $2019-1$ & $2019-2$ & 2020 & $2021-1$ \\
\hline FREQ & 321 & 585 & 1,484 & 2,515 & 2,374 & 5,319 & 582,853 & 164,048 \\
PER MIL & 1.44 & 2.01 & 2.18 & 2.96 & 2.38 & 5.38 & 223.50 & 124.62 \\
\hline
\end{tabular}

These results may suggest that the causes of the pandemic are perhaps of a lesser concern or interest lately and have thus been discussed less extensively in the press than its most immediate effect or consequence. Interestingly, there are also significant diatopic variations in the frequency of occurrence of the two compound expressions. Malaysia stands out as the country where spillover has been most frequently used in newspapers and magazines (Figure 1), while South Africa and India are the two countries where lockdown appears the most (Figure 2). 
Figure 1. Frequencies by country of spillover in the NOW Corpus

\begin{tabular}{|l|c|c|c|l}
\hline SECTION & RREQ & SIZE (M) & PER MLL & CLICK FOR CONTEXT (SEE ALL) \\
\hline United States & 1549 & $2,358.0$ & 0.66 & \\
\hline Canada & 751 & $1,206.0$ & 0.62 & \\
\hline Great Britain & 422 & $1,238.6$ & 0.34 & \\
\hline Ireland & 200 & 780.9 & 0.26 & \\
\hline Australia & 404 & 748.0 & 0.54 & \\
\hline New Zealand & 301 & 426.2 & 0.71 & \\
\hline India & 1104 & $1,117.5$ & 0.99 & \\
\hline Sri Lanka & 93 & 71.0 & 1.31 & \\
\hline Pakistan & 521 & 295.4 & 1.76 & \\
\hline Bangladesh & 73 & 63.8 & 1.14 & \\
\hline Malaysia & 1076 & 285.5 & 3.77 & \\
\hline Singapore & 621 & 429.9 & 1.44 & \\
\hline Philippines & 518 & 334.0 & 1.55 & \\
\hline Hong Kong & 83 & 51.1 & 1.62 & \\
\hline South Africa & 311 & 580.1 & 0.54 & \\
\hline Nigeria & 372 & 567.4 & 0.66 & \\
\hline Ghana & 108 & 137.4 & 0.79 & \\
\hline Kenya & 133 & 193.8 & 0.69 & \\
\hline Tanzania & 20 & 23.9 & 0.84 & \\
\hline Jamaica & 31 & 44.2 & 0.70 & \\
\hline
\end{tabular}

Figure 2. Frequencies by country of lockdown in the NOW Corpus

\begin{tabular}{|l|c|c|c|l|}
\hline SECTION & FREQ & SIZE (M) & PERMIL & CLCK FOR CONTEXT (SEEALL) \\
\hline United States & 68926 & $2,358.0$ & 29.23 & \\
\hline Canada & 11553 & $1,206.0$ & 9.58 & \\
\hline Great Britain & 66701 & $1,238.6$ & 53.85 & \\
\hline Ireland & 22729 & 780.9 & 29.11 & \\
\hline Australia & 17165 & 748.0 & 22.95 & \\
\hline New Zealand & 23518 & 426.2 & 55.18 & \\
\hline India & 93423 & $1,117.5$ & 83.60 & \\
\hline Sri Lanka & 2331 & 71.0 & 32.82 & \\
\hline Pakistan & 12232 & 295.4 & 41.42 & \\
\hline Bangladesh & 3181 & 63.8 & 49.25 & \\
\hline Malaysia & 4322 & 285.5 & 15.14 & \\
\hline Singapore & 12031 & 429.9 & 27.98 & \\
\hline Philippines & 7784 & 334.0 & 23.31 & \\
\hline Hong Kong & 2484 & 51.1 & 48.58 & \\
\hline South Africa & 57501 & 580.1 & 99.12 & \\
\hline Nigeria & 20976 & 567.4 & 36.97 & \\
\hline Ghana & 2482 & 137.4 & 18.07 & \\
\hline Kenya & 3639 & 193.8 & 18.78 & \\
\hline Tanzania & 612 & 23.9 & 25.62 & \\
\hline Jamaica & 322 & 44.2 & 7.29 & \\
\hline
\end{tabular}

The current coronavirus crisis seems to have impacted the frequency of use of these two compounds, the interpretation of which is licensed by metaphoric mapping operations: in the case of spillover, the act of flowing out of a container is taken to refer to the cross-species transmission of a virus and, in the case of lockdown, the concept of imprisonment or forced confinement due to psychiatric reasons is extended to include, more generically, a state of imposed isolation as a public health measure.

\subsection{Free Word Combinations: Chinese Virus, China Virus and Anxiety Pandemic}

Chinese virus and China virus are two novel expressions that were first coined by the former U.S. President Donald Trump to refer to the new coronavirus that supposedly spread from Wuhan in China to the rest of the world in 2020. They are both based on antonomasia and have a polemical/pejorative/offensive connotation, because they implicitly communicate that what comes from China is bad and dangerous, thus fuelling anti-Chinese sentiments. As in the case of other ad hoc formations, they are not lexically entrenched and are 
employed to serve the purpose of economically naming a more elaborate concept or scenario by relying on shared knowledge. However, the fact that they have been used repeatedly in the past few months does not make it possible to exclude that they will end up in the lexicon at some point. As a matter of fact-although there are just two occurrences of Chinese virus and one of China virus in the NOW Corpus before 2020 - their frequency has drastically increased in 2020 and in the first half of 2021 (Table 9).

Table 9. Frequencies of occurrence of Chinese virus and China virus in the NOW Corpus

\begin{tabular}{lllllllll}
\hline & \multicolumn{7}{l}{ Chinese virus } & \multicolumn{7}{c}{ China virus } \\
\cline { 2 - 10 } & 2018 & 2019 & 2020 & $2021-1$ & 2018 & 2019 & 2020 & $2021-1$ \\
\hline FREQ & 1 & 1 & 1,843 & 412 & 0 & 1 & 2,007 & 1,019 \\
PER MIL & 0.00 & 0.00 & 0.71 & 0.31 & 0.00 & 0.00 & 0.77 & 0.77 \\
\hline
\end{tabular}

The coronavirus crisis has had an impact at various levels, including our mental health. The spread of the virus has caused the onset of worries and fears for different reasons. Hence, the expression anxiety pandemic retrieved in the NOW Corpus, which by implicit analogy to the more common virus pandemic refers to anxiety as a living and infectious agent capable of spreading from person to person and across countries. However, differently from the case of Chinese virus and China virus, there is an insufficient number of corpus occurrences of anxiety pandemic as yet to let us suppose that it will soon attain a more stable lexical status (Note 24).

\section{Conclusions}

The present paper has examined some cases of lexical change and innovation resulting from new conditions determined by the current coronavirus crisis. As on many other past occasions, this is proof that extra-linguistic factors may ultimately affect language structure and meaning construction processes. We have observed that certain already existing lexical items tend to be used more frequently now than in the past; others appear to be undergoing a re-adaptation of their semantic range and, perhaps more interestingly, new ones seem to have emerged and to be making their way into dictionaries.

It is probably still too early to determine the full extent of lexical variation further to the coronavirus outbreak. However, the fact that already existing words and expressions are now being used differently and that new items have started to appear seems to suggest that a certain degree of lexical change is under way. To test this hypothesis, a more extensive investigation including a wider range of items is needed. In addition, the corpus queried for the analysis consists only of written data, but it would also be useful to monitor how spoken language evolves to accommodate new communicative needs. It is indeed while speaking that we often produce innovations, which only later become established in written, more formal language.

\section{References}

Bauer, L. (1988). Introducing Linguistic Morphology. Edinburgh University Press.

Benczes, R. (2006). Creative compounding. John Benjamins. https://doi.org/10.1075/hcp.19

Booij, G. (2014). The structure of words. In J. Taylor (Ed.), The Oxford Handbook of the Word (pp. 157-174). Oxford University Press. https://doi.org/10.1093/oxfordhb/9780199641604.013.002

Booij, G. (2017). The construction of words. In B. Dancygier (Ed.), The Cambridge Handbook of Cognitive Linguistics (pp. 229-246). Cambridge University Press. https://doi.org/10.1017/9781316339732.016

Booij, G. (2018). The construction of words: Introduction and overview. In G. Booij (Ed.), The construction of words. Advances in Construction Morphology (pp. 3-18). Springer. https://doi.org/10.1007/978-3-319-74394-3_1

Brinton, L. J., \& Closs, T. E. (2005). Lexicalization and language change. Cambridge University Press. https://doi.org/10.1017/CBO9780511615962

Fellbaum, C. (2007). Idioms and Collocations. Corpus-based Linguistic and Lexicographic Studies, Continuum.

Gries, S. T. (2013). 50-something years of work on collocations. International Journal of Corpus Linguistics, 18(1), 137-165. https://doi.org/10.1075/ijcl.18.1.09gri

Herbst, T. et al. (Eds.) (2011). The Phraseological View of Language. A Tribute to John Sinclair, Berlin/Boston, Mouton de Gruyter. https://doi.org/10.1515/9783110257014

Jespersen, O. (1942). A Modern English Grammar. Ejnar Munksgaard. 
Lieber, R., \& Stekauer, P. (2009). The Oxford Handbook of Compounding. Oxford, Oxford University Press.

Lipka, L. (2002). English Lexicology: Lexical Structure, Word Semantics \& Word-formation. Max Niemeyer Verlag.

Meyer, I., \& Mackintosh, K. (1994). Phraseme analysis and concept analysis: Exploring a symbiotic relationship in the specialized lexicon. In W. Martin et al. (Eds.), Euralex 1994: Proceedings (pp. 339-348). International Congress on Lexicography.

Stubbs, M. (2001). Words and Phrases. Blackwell.

\section{Notes}

Note 1 . The NOW corpus consists of 10.6 billion words from web-based newspapers and magazines from 2010 to the present day. The corpus was last accessed on 15 July 2021 (https://www.english-corpora.org/now/); the last addition to it was made the day before.

Note 2. Therefore, all lexemes are words, but not all words are lexemes.

Note 3. If a word has only one shape the distinction between 'lexeme' and 'word' does no longer hold. The minimum number of word forms for a lexeme is two. That minimum is represented in English by verbs such as must and ought, which only have two forms, i.e., must, ought (present tense neutral) and mustn't, oughtn't (present tense negative). The lexeme be, on the other hand, holds the record for having the maximum number of separate word forms (am, are, aren't, been, be, being, is, isn't, was, wasn't, were, weren't).

Note 4. In the present paper, 'lexical unit' is taken to refer both to a single word and to a multiword combination.

Note 5. Similarly to 'lexeme', the word 'phraseme' also refers to an abstract concept, but it indicates a basic unit of analysis at the phraseological level.

Note 6. Phraseological units can only be made up of separate words, instead.

Note 7. Cf. Booij $(2017,2018)$ for thorough definitions and discussions of word formation processes in English.

Note 8. https://public.oed.com/blog/tag/covid-19/

Note 9. The Oxford English Corpus consists of over 10 billion words of web-based news content from 2017 to the present day (https://www.sketchengine.eu/oxford-english-corpus/).

Note 10. Cf. Herbst et al. (2011) for various contributions on the classificatory aspect of word combinations.

Note 11. https://www.urbandictionary.com/define.php?term=helicopter\%20money

Note 12. https://en.wikipedia.org/wiki/Helicopter_money

Note 13. "Let us suppose now that one day a helicopter flies over this community and drops an additional $\$ 1,000$ in bills from the sky, which is, of course, hastily collected by members of the community. Let us suppose further that everyone is convinced that this is a unique event which will never be repeated." (Milton Friedman, "The Optimum Quantity of Money", 1969). https://www.brookings.edu/blog/ben-bernanke/2016/04/11/what-tools-does-the-fed-have-left-part-3-helicopter-m oney

Note 14. This could be the consequence of slow economic growth and inflation across Europe in 2016.

Note 15. If we query OneLook, a search engine that indexes dictionary sites from across the Web, corona bonds seems to be present (https://www.onelook.com/? $\mathrm{w}=$ corona+bond\&ls $=\mathrm{a}$ ), but in fact we are then redirected to a Wikipedia page (https://en.wikipedia.org/wiki/Eurobond_(eurozone)\#Corona_bond) and even there it is used in inverted commas to indicate that it does not have an official lexical status.

Note 16. https://financial-dictionary.thefreedictionary.com/recovery+fund

Note 17. https://www.politico.eu/author/paul-ames/feed/

Note 18. Helicopter money, corona bonds/funds and recovery bonds/funds might be mistaken for endocentric compounds, but the fact that they cannot appear as single words (*helicoptermoney, *coronabonds, *coronafunds, * *ecoverybonds, *recoveryfunds) or as hyphenated combinations (*helicopter-money *corona-bonds, *corona-funds, *recovery-bonds, *recovery-funds) indicates that they are still only collocations.

Note 19. Cf. Gries (2013) for a detailed discussion on collocations.

Note 20. Distancing, for instance, collocates both with physical and social; intelligent working, and not just 
smart working, also seems possible (e.g., Google Book Search: Whyte, G., 2015, Intelligent working is all about optimizing the resources you have at your disposal), and so forth.

Note 21. This is somewhat odd, because compounds such as smartphone, smartwatch, smart growth, smart sanction, etc., are already well represented.

Note 22. https://thehill.com/homenews/administration/263264-obama-extols-virtues-of-immigration-refugees

Note 23. We can observe that this first use of spillover is already metaphorical, because it does not literally refer to a liquid pouring over the edge of a container.

Note 24. There are only twelve occurrences of anxiety pandemic in the NOW Corpus in 2020 and none in the first half of 2021.

\section{Copyrights}

Copyright for this article is retained by the author, with first publication rights granted to the journal.

This is an open-access article distributed under the terms and conditions of the Creative Commons Attribution license (http://creativecommons.org/licenses/by/4.0/). 